\title{
Numerical model of beem-to-column joint finite stifness
}

\author{
Ruslan I. Bagautdinov, Yuriy P. Komarov, Nikolaiy N. Mostovskiy, Zaur S. Daurov \\ Peter the Great St. Petersburg Polytechnic University (SPbPU), \\ 29 Polytechnicheskaya st., St. Petersburg, 195251, Russian Federation
}

\begin{abstract}
Introduction. One of the greatest accents in the steel structures researches is the optimization of the design model. It is possible to reduce the cost of steel structures, optimize moment distribution and dynamic characteristics of the frame using the finite secant stiffness, which can be obtained by the described in the paper numerical modeling method. There are a lot of perspectives for the engineer in the field of numerical modeling. Most of them are possible to implement in the design procedure nowadays, but it is important to develop methods and standards for numerical modeling, in order to obtain convenient tools and reliable results. In order to study this issue in more depth, the "moment - turn" curve was studied, maximum stress values were determined, and rigidity and strength characteristics were prepared for each type of joint for structural analysis.

Materials and methods. In the program Ansys was modelling three types of steel joints: end-plate connections, double web-angle connections and top and seat angle connections.

Results. For three types of joints was obtained ultimate moment, location of destruction and moment-rotation curve. For extended end-plate connections was comparison of the obtained curve with experimental data.

Conclusions. Three types of steel joints were modeled in the paper. The numerical modeling results show good correlation with the experimental ones. The data about the behavior of the joints were extracted and analyzed. As result, "moment-angle of rotation" curves were obtained. Finite secant stiffness of the joints for considering steel structures was obtained in the analysis. The resulting finite secant stiffness can be used in the steel frames design procedure.
\end{abstract}

KEYWORDS: semi-rigid connections, finite stiffness, secant stiffness, end-plate connection, double-web angle connection, numerical modelling, moment-rotation curve, non-linear analysis

FOR CITATION: Bagautdinov R.I., Komarov Yu.P., Mostovskiy N.N., Daurov Z.S. Numerical model of beem-to-column joint finite stifness. Vestnik MGSU [Proceedings of Moscow State University of Civil Engineering]. 2019; 14:2:179-187. DOI: 10.22227/1997-0935.2019.2.179-187

\section{Численное моделирование конечной жесткости узлов колонны с балкой}

\author{
Р.И. Багаутдинов, Ю.П. Комаров, Н.Н. Мостовский, З.С. Дауров \\ Санкт-Петербургский политехнический университет Петра Великого (СПбПУ), \\ 195251 , г. Санкт-Петербург, ул. Политехническая, д. 29
}

\begin{abstract}
АННОТАЦИЯ
Введение. Один из важнейших аспектов в исследовании металлоконструкций - совершенствование проектной модели. Возможно снижение стоимости стальных конструкций, оптимизация распределения усилий в элементах металлического каркаса и динамических характеристик каркаса с использованием метода конечных секущих жесткостей, которые могут быть получены описанным методом численного моделирования. Для инженера в области численного моделирования открывается много перспектив. Большинство из них в настоящее время возможно реализовать в проектировании, но необходимо разработать методы и стандарты численного моделирования для получения удобных инструментов и достоверных результатов. Чтобы глубже изучить данный вопрос была изучена кривая «момент - поворот», определены максимальные значения напряжений и подготовлены характеристики жесткости и прочности для каждого типа соединения для структурного анализа.

Материалы и методы. В программном комплексе Ansys было смоделировано три типа узлов металлоконструкций: фланцевый узел, узел на верхнем и опорном уголках и узел на двух уголках на стенке балки. В качестве нелинейной модели материала использовалась трилинейная диаграмма.

Результаты. Произведен расчет смоделированных узлов. В результате анализа для трех типов узлов получены предельный момент, место разрушения узла и кривая «момент - поворот». Также для фрланцевого узла осуществлено сравнение полученных результатов с экспериментальными данными.

Выводы. Результаты численного моделирования хорошо коррелируют с экспериментальными данными. Были извлечены и проанализированы данные о поведении полужесткого соединения. В результате анализа получена конечная секущая жесткость трех типов узлов. Ее можно использовать при проектировании металлических каркасов. Это позволит уменьшить стоимость металлического каркаса, оптимизировать распределение усилий в его элементах.
\end{abstract}

кЛЮчЕВЫЕ СлоВА: полужесткие узлы, конечная жесткость, секущая жесткость, фрланцевое соединение, узел на верхнем и опорном уголке, численное моделирование, кривая «момент - поворот», нелинейный анализ 
для цитИ РовАния: Багаутдинов Р.И., Комаров Ю.П., Мостовский Н.Н., Дауров З.С. Численное моделирование конечной жесткости узлов колонны с балкой // Вестник МГСУ. 2019. Т. 14. Вып. 2. С. 179-187. DOI: 10.22227/19970935.2019.2.179-187

\section{INTRODUCTION}

There are many ways to consider the final cost of the structures and to define, which of their different variations are the most effective from different points of view. The research of Jaakko Haapio [1] is conducted in Tampere University of Technology, which aims to develop a method that allows determining the manufacturing and installation costs of steel structures already at the tender phase while taking into account their details.

Different construction materials have to be considered in conjunction with its properties, a way of behavior and manufacturing process. The particular qualities of steel structures have been studied a lot during last centuries, which makes possible for an engineer to use advanced design techniques and to take into account complex of economic, ecologic and safety factors. Instead of increasing complexity of the design procedure, it becomes common practice to use the modern analysis software and computing technologies, which makes it even easier.

The procedure of skeletal steel structures design can be presented in following steps:

1. Introduce the initial members and joints into a product model with joint spring factors/moment resistances.

2. Execute the structural analysis with initial member sections and joints.

3. Check the manufacturer's profile and joint databases.

4. Check stresses of the members and shear stresses of the joints (moment check of joint is not needed as the moment of a joint is limited to full resistance).

5 . Increase or decrease member and/or joint sizes according to the structural analysis.

6. When sizes are adequate, estimate the cost of the frame.

7. Vary the joint type with new joint parameters.

8. Repeat steps 1-5.

9. Choose the optimal alternative.

Modern steel structures researches aiming to find a considerable way to conduct optimization of the design model. The most valuable way is accounting with joint stiffness of steel structures.

Most of the research was focused on the application of these methods to the analysis of structures with semi-rigid joints [2-11]. By the 1960s, the matrix stiffness method of structural analysis utilizing computers had been established. Monforton and $\mathrm{Wu}$ were the first to incorporate the effects of semi-rigid connections into the matrix stiffness method in 1963.

The report 23 on the European recommendations for steel constructions was published by European Convention for Structural Steelwork in 1978. Eurocode 3 is based on this report. These recommendations are replaced method allowable stress in the limiting state method, based on probabilistic concepts of safety and use load gain for the analysis of structural stability and resistance instead of the traditional reference to the allowable stress. The Commission of the European Community produced the first version of Eurocode 3 in 1984. The document was published on a trial basis (European Pre-Standard, ENV), in which were offered comments from users, as well as professional, scientific, and technical standards organizations.

Their replies were used to improve the final version. The document was published on a trial basis (European Pre-Standard, ENV), in which were offered comments from users, as well as professional, scientific, and technical standards organizations. In 1989 this work was transferred to the European Committee for Standardization (CEN) The Eurocode has evolved [12-14], and finally in May 2005, the Eurocode 3 was published. It was exclusively dedicated to all types of joints, including semi-rigid ones, where the response of a joint is dependent on the geometric and mechanical properties of its components, using the component method [15]. This practice document is a result of many years of research in steel structures. There are also another practical codes that also take into consideration joint behavior: the US in AISC-ASD, LRFD, AISCASD/LRFD, and China in the UK [11, 12, 16-18].

The reasons for the beginning of numerical simulation are presented below:

(1) the lack of experimental results;

(2) insufficient accuracy of local effects measurement;

(3) to create a large range of parametric studies.

FE-analysis (FEA) is ideal for determining the corotation. However, this analysis is still expensive. The torque curve is the result of complex interactions between the different elements of the joint.

The aim of the paper is to conduct finite element modeling (FEM) of steel joints and to provide analysis of the FEM results. In order to provide deeper look in the FEM the moment-rotation curve was studied, the maximum stress values was determined and the stiffness and strength characteristics for each joint type was prepared for the structural analysis. 


\section{MATERIALS AND METHODS}

The material nonlinear model (fig. 1) is a tri-linear diagram [19] where the model of following models of elasticity were chosen.

1. For (a)-zone: models of elasticity $E$.

2. For (b)-zone: $E_{h 1}=\mathrm{E} / \mathrm{CWH}$, where $\mathrm{CWH}$ is hardening coefficient.

3. For (c)-zone: $E_{h 2}=\mathrm{EH} 1 / 10$ in order to solve FEA problems.

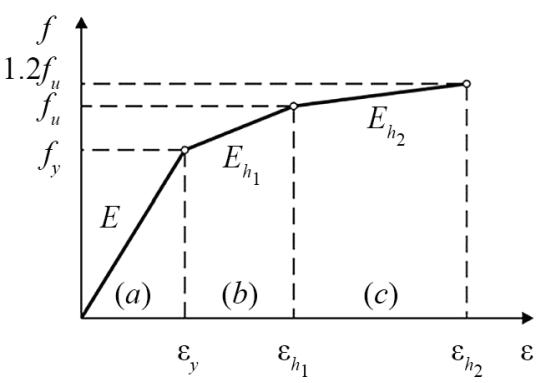

Fig. 1. Tri-linear diagram of steel

Joint type can be chosen by the moment rotation characteristic obtained by FEM program ANSYS. The FEM model is based on experiment conducted by Jenss [19]. The results are in the SERICON database with the number T101.010.

FEM model was calculated by stage loading. Bolt pretension was included into analysis. The loads was applied till the ultimate moment occurs. That was obtained according to the Eurocode methodology [20].

Physical and geometrical non-linearity was accounted in a FEM analysis in ANSYS by NewtonRaphson method with convergence criteria of $0.5 \%$ and friction coefficient 0.5 [20].

To obtain the finite rigidity the moment due to angle is used. It is necessary to determine the secant stiffness from the value of limit torque and corresponding rotation of the joint.

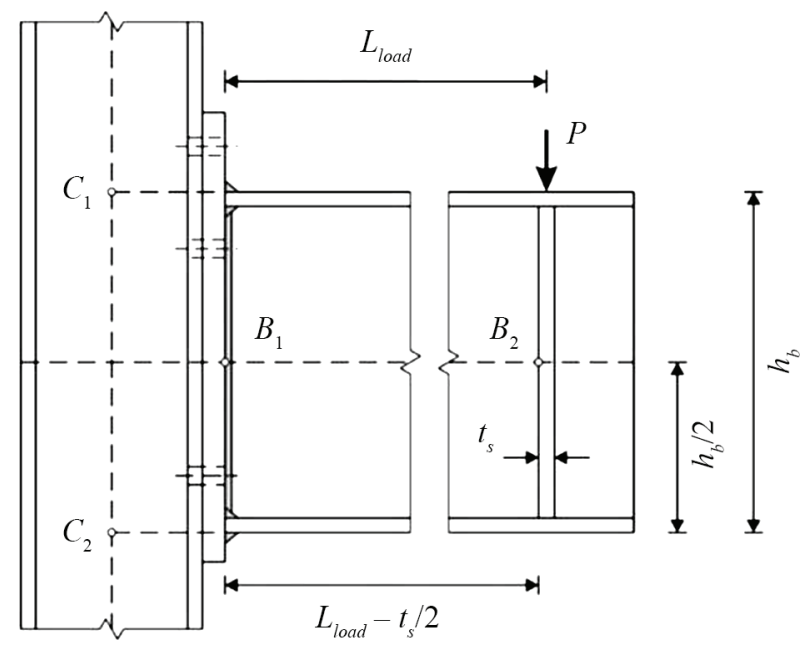

The following formulas were used to calculate the characteristics for making the curve $(M j-\theta j)$.

The obtained curve was compared with the experimental curve.

The torque at the joint was calculated according to the formula (1), where (P) is the force applied to the free end of the beam, and (Lload) is the arm of the force application.

$$
M j=P \cdot L_{\text {load }} .
$$

The rotational deformation of the joint $\left(\varphi_{j}\right)$ is the sum of the shear deformation of the column web panel zone $(\gamma)$ and of the connection rotational deformation

$$
\varphi j=\theta c+\gamma .
$$

Displacement at points (B1, B2, C1 and C2) are used for definitions of required values:

$$
\begin{gathered}
\varphi_{j}=\operatorname{atan}\left(\frac{v_{B 2}-v_{B 1}}{d_{B}}\right)-\theta_{e l, c}-\theta_{e l, B} \varphi_{j}= \\
=\operatorname{atan}\left(\frac{v_{B 2}-v_{B 1}}{d_{B}}\right)-\theta_{e l, c}-\theta_{e l, B} ; \\
\gamma=\operatorname{atan}\left(\frac{U_{C 2}-U_{C 1}}{h_{b}}\right)-\theta_{e l, c} \gamma= \\
=\operatorname{atan}\left(\frac{U_{C 2}-U_{C 1}}{h_{b}}\right) \theta_{e l, c} ; \\
\theta c=\varphi j-\gamma,
\end{gathered}
$$

where $V_{B 1}, V_{B 2}$ - vertical displacement at points $\mathrm{B} 1$ and B2 (fig. 2); $d_{B}$ - is the distance between points B1 and B2; $\theta_{e l, c}$ - is the theoretical column elastic rotation:

$$
\theta_{e l, c}=\frac{5 \cdot M_{j} \cdot\left(H-h_{c}\right)}{64 \cdot E \cdot l_{c}},
$$

$\theta_{e l, b}$ - is the beam elastic rotation:

$$
\theta_{e l, c}=\frac{-P}{E \cdot l_{b}}\left(\frac{d_{B}^{2}}{6}-\frac{L_{\text {load }} \cdot d_{B}}{2}\right),
$$

Fig. 2. Design scheme 
Table 1. Initial data for extended end-plate connections

\begin{tabular}{l|c|c|c|c}
\hline \multicolumn{1}{c|}{ Element } & Yield stress, fy & Ultimate stress fu, MPa & $\begin{array}{c}\text { Elasticity modulus E, } \\
\mathrm{MPa}\end{array}$ & Poisson number \\
\hline Flange of beam & 303.0 & 447.0 & & \\
\cline { 1 - 3 } Web of beam & 314.0 & 443.0 & \multirow{2}{*}{210000} & \\
\cline { 1 - 3 } Flange of column & 280.0 & 422.3 & \multirow{2}{*}{0.3} \\
\cline { 1 - 3 } Web of column & 298.8 & 422.0 & \\
\cline { 1 - 3 } Bolts & 900.0 & 1000.0 & & \\
\hline End-plate & 291.5 & 463.4 & \\
\end{tabular}

Table 2. Geometrical parameters for extended end-plate connections

\begin{tabular}{l|c}
\hline \multicolumn{1}{c|}{ Parameter } & Values \\
\hline Cross section of column & HE 160 B \\
\hline Cross section of beam & IPE 300 \\
\hline Cross section of end-plate & $380 \times 150 \times 20 \mathrm{~mm}$ \\
\hline Diameter of bolts & $20 \mathrm{~mm}$
\end{tabular}

Table 3. Geometrical parameters for double web angle connections and top and seat angle connections

\begin{tabular}{l|c|c}
\hline \multicolumn{1}{c|}{ Parameter } & Double-Web Angle connection & Top and Seat angle connections \\
\hline Cross section of column & $\mathrm{W} 12 \times 96$ & $\mathrm{~W} 12 \times 96$ \\
\hline Cross section of beam & $\mathrm{W} 14 \times 38$ & $\mathrm{~W} 14 \times 38$ \\
\hline Cross section of angle & $2 \mathrm{~L} 4 \times 3-1 / 2 \times 1 / 4$ & $\mathrm{~L} 6 \times 4 \times 1 / 2$ \\
\hline Diameter of bolts & $19.1 \mathrm{~mm}$ & $22 \mathrm{~mm}$
\end{tabular}

$I_{c}, I_{b}$ - are the second moment of areas of the column and beam; $U_{C 1}, U_{C 2}$ - are the horizontal displacements at points $\mathrm{C} 1$ and $\mathrm{C} 2$.

For end-plate connection, the initial data are presented in the tables below (table 1).

For double-web angle connection and top and seat angle connection are used next materials:

- A325 Bolts;

- Other elements A36 Steel.

Geometrical parameters of this connections are shown in table below (table 2, 3).

\section{RESULTS}

Structural analysis programs usually require as an input data to define whether it is used pinned or rigid joint type in the analysis model. It affects the results of calculations as a type of joint defines not only a moment distribution in the construction, but also effective length of the column and beam, dynamic characteristics and accuracy of the analysis. Also, it is possible to consider non-linear model of "moment-angle of rotation" curve. The relation between the moment and the angle of rotation determined by the different mathematical models. In accordance with component method, presented in Eurocode 3 and Finite Element Analysis programs it became possible to conduct with joint stiffness and to find the most optimal joint type for the current structure and load factors.

In the program Ansys was built 3 models of connections, shown in fig. 3 .

For extended end-plate connection the $M_{U}=$ $=55 \mathrm{kN} / \mathrm{m}$ (fig. 4), where destruction occurs in the compression zone of the column web.

For the double web angle connection the $M_{U}=$ $=21 \mathrm{kN} / \mathrm{m}$, where destruction occurs in the beam web (fig. 5).

For the top and seat angle connection the $M_{U}=$ $=35 \mathrm{kN} / \mathrm{m}$, where destruction occurs in the top angle (fig. 6).

At the figures below the results of "moment-angle of rotation" modeling was presented (fig. 7-9).

A comparison of the obtained curve "moment-rotation" with experimental curve was made for extended end-plate connections. Analysis of the results showed that the destruction in the joint was localized in the same place as in the experiment [20, 21]. The resulting curve and the ultimate moment obtained with numerical simulations also correspond to the experimental data.

Secant stiffness of the joint was determined as a ratio between the bending moment and the angle of rotation at that time when the deformation in the joint 

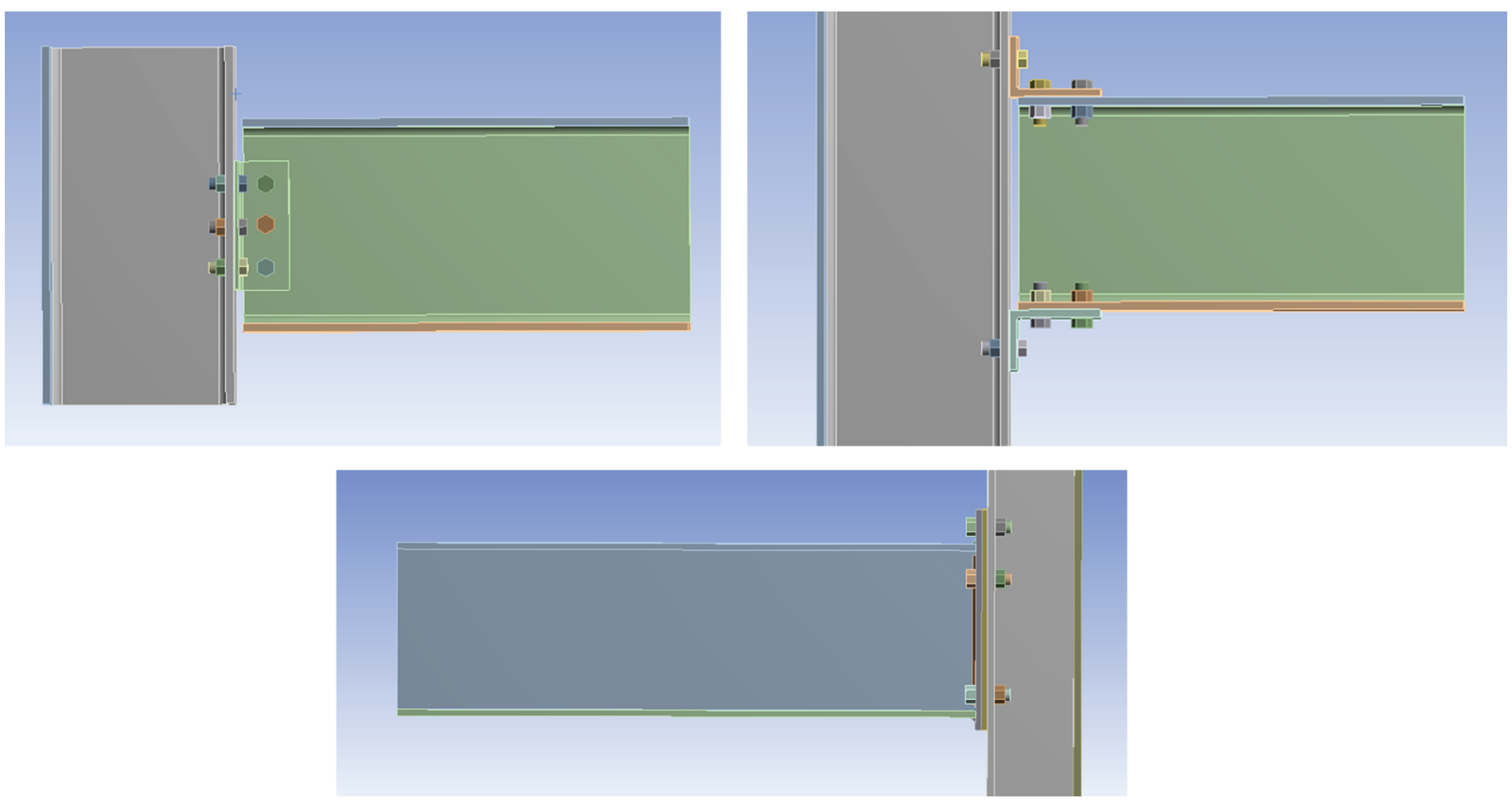

Fig. 3. Connections

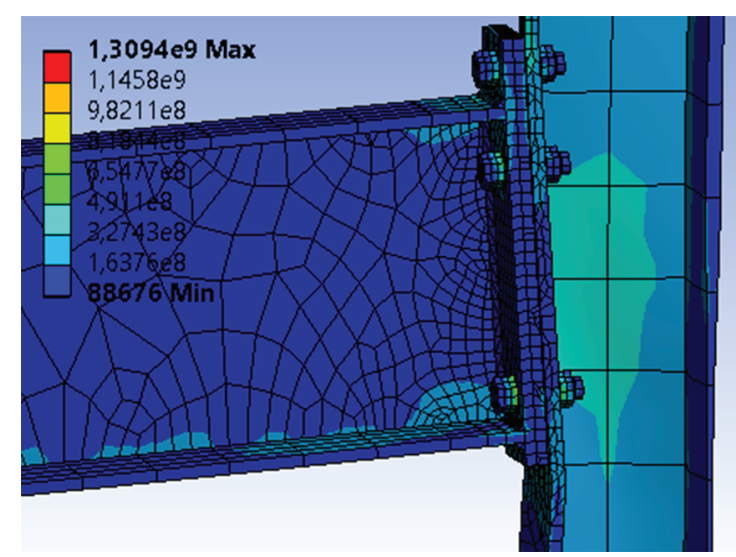

Fig. 4. Extended end-plate connections

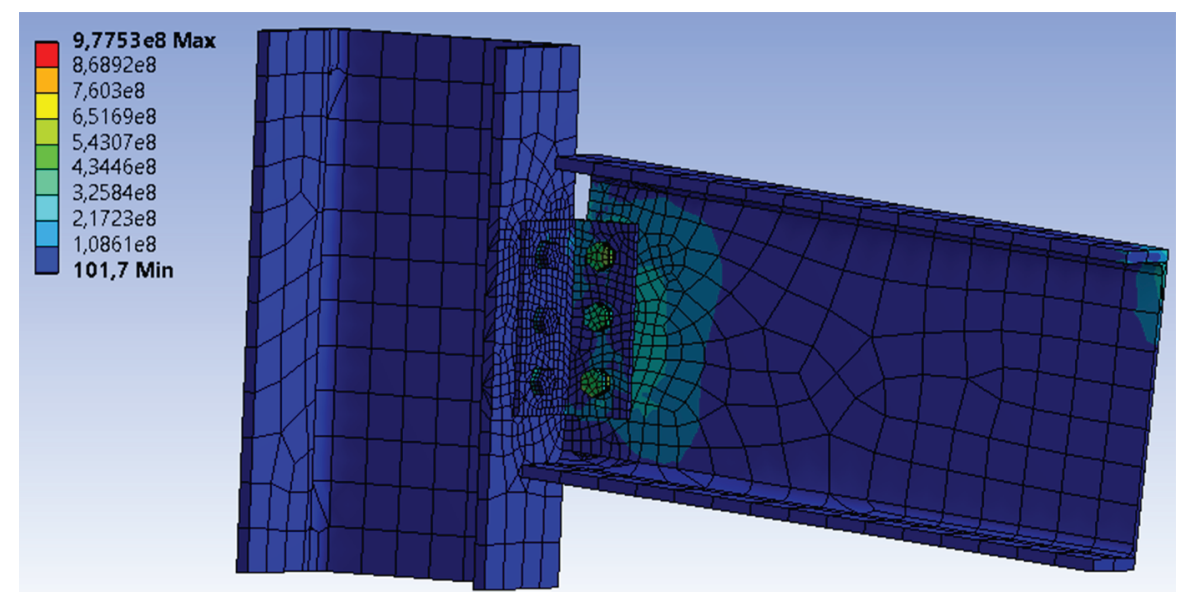

Fig. 5. Double wen angle connections

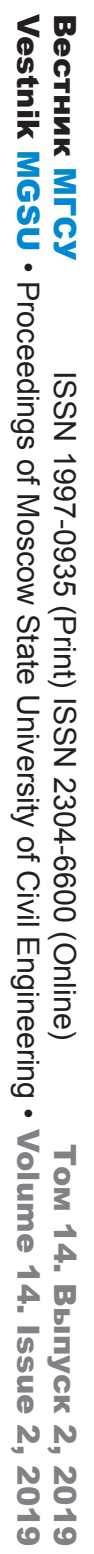




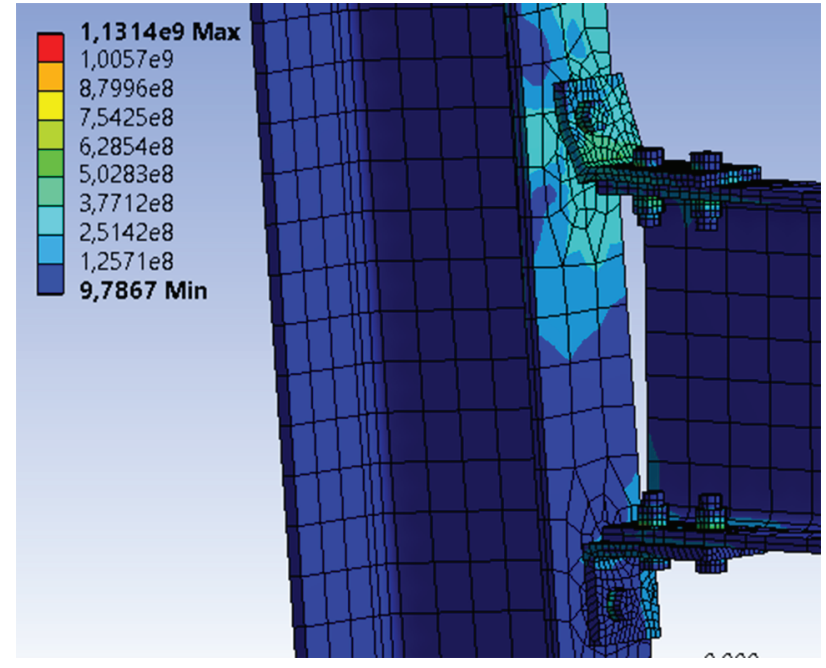

Fig. 6. Top and seat angle connections

End plate connection

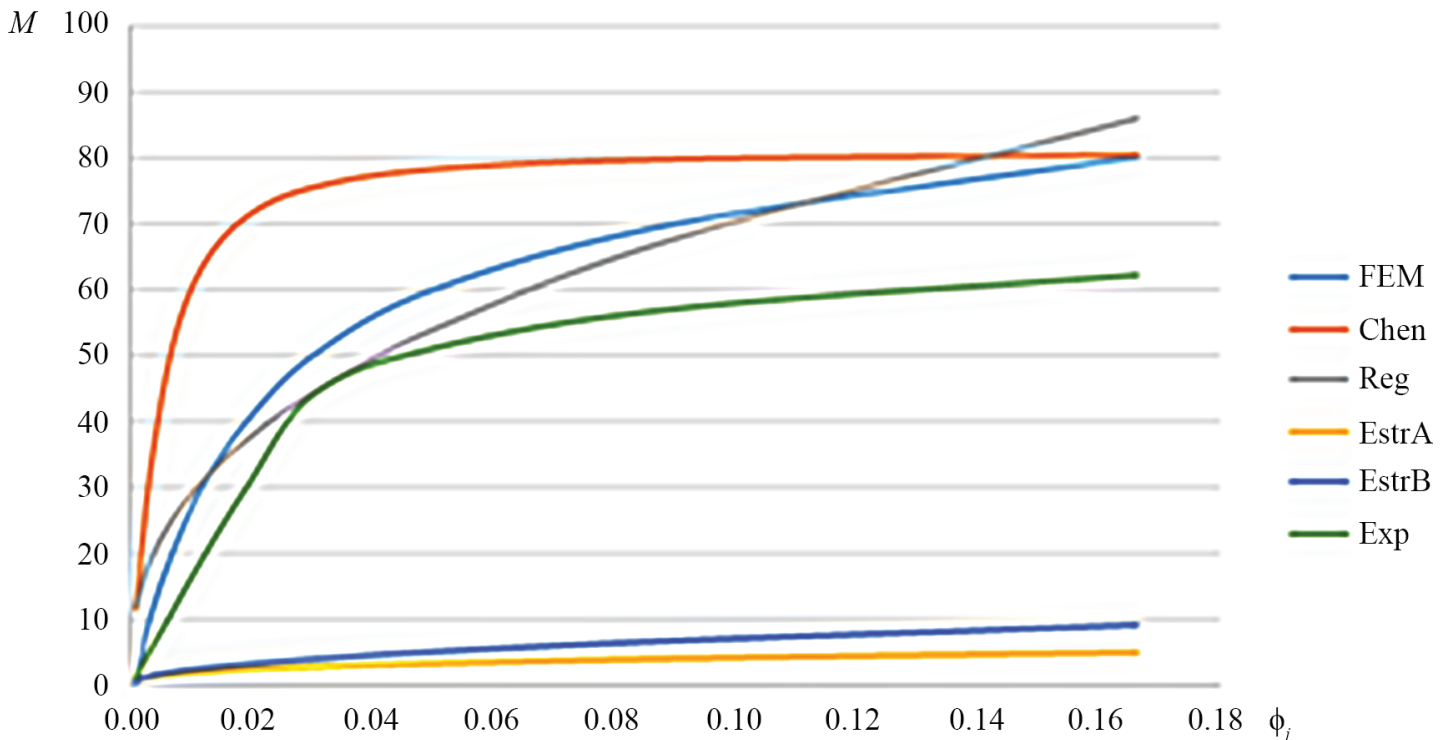

Fig. 7. Results of end plate connection

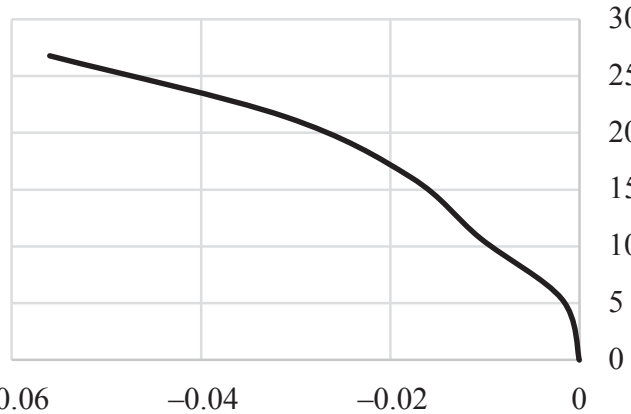

Fig. 8. Results of double web angle connection

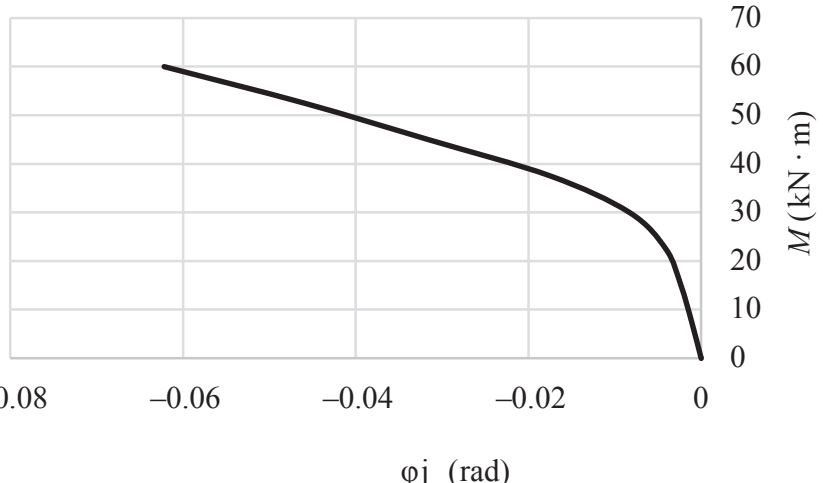

Fig. 9. Top and seat angle connection 
becomes plastic. For extended end-plate connection this value is $55 \mathrm{kN} \cdot \mathrm{m}$ and the angle of rotation at the same moment is $0.032 \mathrm{rad}$. So, the secant stiffness for the extended end-plate joint is $S=1718 \mathrm{kN} \cdot \mathrm{m} / \mathrm{rad}$, for the double web angle connection is $733 \mathrm{kN} \cdot \mathrm{m} / \mathrm{rad}$, for the top and seat angle connection $1680 \mathrm{kN} \cdot \mathrm{m} / \mathrm{rad}$.

Developed models are absolutely parameterized, which allows to quickly change the parameters of the joints, for example column section, size of bolts. It allows to quickly get the secant stiffness of a joint with other geometric and physical characteristics.

\section{CONCLUSIONS AND DISCUSSION}

Numerical modeling is frequently used in modern researches. Steel structures joints can be easily modeled with the help of modern design programs. The usage of modern hardware, algorithms and software improve the performance of calculation. There are a lot of perspectives for the engineer in the field of numerical modeling. Most of them are possible to implement in the design procedure nowadays, but it is important to develop methods and standards for numerical modeling, in order to obtain convenient tools and reliable results.

Three types of steel joints were modeled with software Ansys. The numerical modeling results show good correlation with the experimental ones. The equivalent stress was used for the ultimate moments determination. The data about the behavior of the joints were extracted and analyzed. As result, "moment-angle of rotation" curves were obtained. Finite secant stiffness of the joints for considering steel structures was obtained by the analysis of results.

The resulting finite secant stiffness can be used for the calculation of the steel frames. It is possible to reduce the cost of steel structures, optimize moment distribution and dynamic characteristics of the frame using the finite secant stiffness, which can be obtained by the described in the paper numerical modeling method.

\section{REFERENCES}

1. Haapio J., Heinisuo M. Minimum cost steel beam using semi-rigid joints. Rakenteiden Mekaniikka (Journal of Structural Mechanics). 2010; 43(1):1-11.

2. Hasan M.J., Ashraf M., Uy B. 01.07: Numerical investigation on the semi-rigid behaviour of austenitic stainless steel connections. ce/papers (Special Issue: Proceedings of Eurosteel 2017). 2017; 1(2-3):215-224. DOI: $10.1002 /$ cepa.52

3. Bahaz A., Amara S., Jaspart J.P., Demonceau J.F. Analysis of the behaviour of semi rigid steel end plate connections. MATEC Web of Conferences. 2018; 149:02058. DOI: 10.1051/matecco$\mathrm{nf} / 201814902058$

4. Concepción Díaz, Mariano Victoria, Osvaldo M. Querin, Pascual Martí. Optimum design of semi-rigid connections using metamodels. Journal of Constructional Steel Research. 2012; 78:97-106. DOI: 10.1016/j.jcsr.2012.06.013

5. Pirmoz A., Khoei A.S., Ebrahim Mohammadrezapour E., Daryan A.S. Moment-rotation behavior of bolted top-seat angle connections. Journal of Constructional Steel Research. 2009; 65(4):973-984. DOI: 10.1016/j.jcsr.2008.08.011

6. Pirmoz A., Ahadi P., Farajkhah V. Finite element analysis of extended stiffened end plate link-tocolumn connections. Steel Construction. 2016; 9(1):4657. DOI: $10.1002 /$ stco. 201350003

7. Smitha M.S., Babu S. Behaviour of top and seat angle semi-rigid connections. Journal of the Institution of Engineers (India): Series A. 2013; 94(3):153-159. DOI: $10.1007 / \mathrm{s} 40030-014-0050-6$

8. Shi G., Chen X. Moment-rotation curves of ultra-large capacity end-plate joints based on compo- nent method. Journal of Constructional Steel Research. 2017; 128:451-461. DOI: 10.1016/j.jcsr.2016.09.012

9. Shi G., Chen X., Wang D. Experimental study of ultra-large capacity end-plate joints. Journal of Constructional Steel Research. 2017; 128:354-361. DOI: 10.1016/j.jcsr.2016.09.001

10. Kong Z., Kim S.-E. Numerical estimation of the initial stiffness and ultimate moment capacity of single-web angle connections. Journal of Constructional Steel Research. 2016; 121:282-290. DOI: 10.1016/j. jcsr.2016.02.011

11. Concepción Díaz, Pascual Martí, Mariano Victoria, Osvaldo M. Querin. Review on the modelling of joint behaviour in steel frames. Journal of Constructional Steel Research. 2011; 67(5):741-758. DOI:10.1016/j.jcsr.2010.12.014

12. Pirmoz A., Liu M.M. Direct displacementbased seismic design of semi-rigid steel frames. Journal of Constructional Steel Research. 2017; 128:201-209. DOI: 10.1016/j.jcsr.2016.08.015

13. Kim J.H., Ghaboussi J., Elnashai A.S. Mechanical and informational modeling of steel beamto-column connections. Engineering Structures. 2010; 32(2):449-458. DOI: 10.1016/j.engstruct.2009.10.007

14. Hantouche E.G., Kukreti A.R., Rassati G.A., Swanson J.A. Modified stiffness model for thick flange in built-up T-stub connections. Journal of Constructional Steel Research. 2013; 81:76-85. DOI: 10.1016/j. jcsr.2012.11.009

15. Bagautdinov R., Monastireva D., Bodak I., Potapova I. Feasibility study tool for semi-rigid joints design of high-rise buildings steel structures. E3S Web 
of Conferences. 2018; 33:02022. DOI:10.1051/e3sconf $/ 20183302022$

16. Dai X.H., Wang Y.C., Bailey C.G. Numerical modelling of structural fire behaviour of restrained steel beam-column assemblies using typical joint types. Engineering Structures. 2010; 32(8):2337-2351. DOI: 10.1016/j.engstruct.2010.04.009

17. Ihaddoudène A.N.T., Saidani M., Jaspart J.P. Mechanical model for determining the critical load of plane frames with semi-rigid joints subjected to static loads. Engineering Structures. 2017; 145:109-117. DOI: 10.1016/j.engstruct.2017.05.005

18. Kong Z., Kim S.-E. Numerical estimation for initial stiffness and ultimate moment of T-stub connections. Journal of Constructional Steel Research. 2018; 141:118-131. DOI: 10.1016/j.jcsr.2017.11.008
19. Concepción Díaz, Mariano Victoria, Osvaldo M. Querin, Pascual Martí. FE Model of threedimensional steel beam-to-column bolted extended end-plate joint. International Journal of Steel Structures. 2018; 18(3):843-867. DOI: 10.1007/s13296018-0033-y

20. Concepción Díaz, Mariano Victoria, Pascual Martí, Osvaldo M. Querin. FE model of beam-to-column extended end-plate joints. Journal of Constructional Steel Research. 2011; 67(10):1578-1590. DOI: 10.1016/j.jcsr.2011.04.002

21. Estrin G.Ya. Determination of bending moments in semi-rigid steel framing joints. Computers \& Structures. 1992; 45(5-6):1109-1117. DOI.10.1016/0045-7949(92)90067-a

Received November 22, 2018

Adopted in a modified form on December 16, 2018

Approved for publication January 29, 2019

\begin{abstract}
A в о т т тн A U т н о S : Ruslan I. Bagautdinov - Postgraduate of Department of Construction Mechanics and Building Structures, Peter the Great St. Petersburg Polytechnic University (SPbPU), 29 Polytechnicheskaya st., St. Petersburg, 195251, Russian Federation, ruslandos93@gmail.com;

Yuriy P. Komarov - undergraduated of Department of Construction Mechanics and Building Structures, Peter the Great St. Petersburg Polytechnic University (SPbPU), 29 Polytechnicheskaya st., St. Petersburg, 195251, Russian Federation, kresnik12@yandex.ru;

Nikolaiy N. Mostovskiy - student, Department of Construction of Unique Buildings and Structures, Peter the Great St. Petersburg Polytechnic University (SPbPU), 29 Polytechnicheskaya st., St. Petersburg, 195251, Russian Federation,n.mostovsky@mail.ru;

Zaur S. Daurov - student, Department of Construction of Unique Buildings and Structures, Peter the Great St. Petersburg Polytechnic University (SPbPU), 29 Polytechnicheskaya st., St. Petersburg, 195251, Russian Federation, zaur25k@gmail.com.
\end{abstract}

\title{
ЛИТЕРАТУРА
}

1. Haapio J., Heinisuo M. Minimum cost steel beam using semi-rigid joints // Rakenteiden Mekaniikka (Journal of Structural Mechanics). 2010. Vol. 43. No. 1. Pp. 1-11.

2. Hasan M.J., Ashraf M., Uy B. 01.07: Numerical investigation on the semi-rigid behaviour of austenitic stainless steel connections // ce/papers (Special Issue: Proceedings of Eurosteel 2017). 2017. Vol. 1. No. 2-3. Pp. 215-224. DOI:10.1002/cepa.52

3. Bahaz A., Amara S., Jaspart J.P., Demonceau J.F. Analysis of the behaviour of semi rigid steel end plate connections // MATEC Web of Conferences. 2018. Vol. 149. P. 02058. DOI:10.1051/matecco$\mathrm{nf} / 201814902058$

4. Concepción Díaz, Mariano Victoria, Osvaldo M. Querin, Pascual Martí. Optimum design of semirigid connections using metamodels // Journal of Constructional Steel Research. 2012. Vol. 78. Pp. 97-106. DOI: $10.1016 / j . j c s r .2012 .06 .013$
5. Pirmoz A., Khoei A.S., Ebrahim Mohammadrezapour E., Daryan A.S. Moment-rotation behavior of bolted top-seat angle connections // Journal of Constructional Steel Research. 2009. Vol. 65. No. 4. Pp. 973-984. DOI: 10.1016/j.jcsr.2008.08.011

6. Pirmoz A., Ahadi P., Farajkhah V. Finite element analysis of extended stiffened end plate link-to-column connections // Steel Construction. 2016. Vol. 9. No. 1. Pp. 46-57. DOI:10.1002/ stco. 201350003

7. Smitha M.S., Babu S. Behaviour of top and seat angle semi-rigid connections // Journal of the Institution of Engineers (India): Series A. 2013. Vol. 94. No. 3. Pp. 153-159. DOI: 10.1007/s40030-014-0050-6

8. Shi G., Chen X. Moment-rotation curves of ultra-large capacity end-plate joints based on component method // Journal of Constructional Steel Research. 2017. Vol. 128. Pp. 451-461. DOI: 10.1016/j. jesr.2016.09.012 
9. Shi G., Chen X., Wang D. Experimental study of ultra-large capacity end-plate joints // Journal of Constructional Steel Research. 2017. Vol. 128. Pp. 354-361. DOI: 10.1016/j.jcsr.2016.09.001

10. Kong Z., Kim S.-E. Numerical estimation of the initial stiffness and ultimate moment capacity of singleweb angle connections // Journal of Constructional Steel Research. 2016. Vol. 121. Pp. 282-290. DOI: 10.1016/j. jcsr.2016.02.011

11. Concepción Díaz, Pascual Martí, Mariano Victoria, Osvaldo M. Querin. Review on the modelling of joint behaviour in steel frames // Journal of Constructional Steel Research. 2011. Vol. 67. No. 5. Pp. 741758. DOI:10.1016/j.jcsr.2010.12.014

12. Pirmoz A., Liu M.M. Direct displacement-based seismic design of semi-rigid steel frames // Journal of Constructional Steel Research. 2017. Vol. 128. Pp. 201209. DOI: 10.1016/j.jcsr.2016.08.015

13. Kim J.H., Ghaboussi J., Elnashai A.S. Mechanical and informational modeling of steel beam-tocolumn connections // Engineering Structures. 2010. Vol. 32. No. 2. Pp. 449-458. DOI: 10.1016/j.engstruct.2009.10.007

14. Hantouche E.G., Kukreti A.R., Rassati G.A., Swanson J.A. Modified stiffness model for thick flange in built-up T-stub connections // Journal of Constructional Steel Research. 2013. Vol. 81. Pp. 76-85. DOI: 10.1016/j.jcsr.2012.11.009

15. Bagautdinov R., Monastireva D., Bodak I., Potapova I. Feasibility study tool for semi-rigid joints design of high-rise buildings steel structures // E3S Web of Conferences. 2018. Vol. 33. P. 02022. DOI:10.1051/ e3sconf $/ 20183302022$

16. Dai X.H., Wang Y.C., Bailey C.G. Numerical modelling of structural fire behaviour of restrained steel beam-column assemblies using typical joint types // Engineering Structures. 2010. Vol. 32. No. 8. Pp. 2337 2351. DOI: 10.1016/j.engstruct.2010.04.009

17. Ihaddoudène A.N.T., Saidani M., Jaspart J.P. Mechanical model for determining the critical load of plane frames with semi-rigid joints subjected to static loads // Engineering Structures. 2017. Vol. 145. Pp. 109-117. DOI: 10.1016/j.engstruct.2017.05.005

18. Kong Z., Kim S.-E. Numerical estimation for initial stiffness and ultimate moment of T-stub connections // Journal of Constructional Steel Research. 2018. Vol. 141. Pp. 118-131. DOI: 10.1016/j. jesr.2017.11.008

19. Concepción Díaz, Mariano Victoria, Osvaldo M. Querin, Pascual Martí. FE model of three-dimensional steel beam-to-column bolted extended end-plate joint // International Journal of Steel Structures. 2018. Vol. 18. No. 3. Pp. 843-867. DOI: 10.1007/s13296-018-0033-y

20. Concepción Díaz, Mariano Victoria, Pascual Marti, Osvaldo M. Querin. FE model of beam-to-column extended end-plate joints // Journal of Constructional Steel Research. 2011. Vol. 67. No. 10. Pp. 15781590. DOI: $10.1016 /$ j.jcsr.2011.04.002

21. Estrin G.Ya. Determination of bending moments in semi-rigid steel framing joints // Computers \& Structures. 1992. Vol. 45. No. 5-6. Pp. 1109-1117. DOI.10.1016/0045-7949(92)90067-a

Поступила в редакиию 22 ноября 2018 г.

Принята в доработанном виде 16 декабря 2018 г.

Одобрена для публикачии 29 января 2019 г.

О в а в Т РА Х: Багаутдинов Руслан Ильдарович - аспирант кафедры строительной механики и строительных конструкций, Санкт-Петербургский политехнический университет Петра Великого (СПбПУ), 195251, г. Санкт-Петербург, ул. Политехническая, д. 29, ruslandos93@gmail.com;

Комаров Юрий Павлович - магистрант кафедры строительной механики и строительных конструкций, Санкт-Петербургский политехнический университет Петра Великого (СПбПУ), 195251, г. СанктПетербург, ул. Политехническая, д. 29, kresnik12@yandex.ru;

Мостовский Николай Николаевич - студент кафедры строительства уникальных зданий и сооружений, Санкт-Петербургский политехнический университет Петра Великого (СПбПУ), 195251, г. СанктПетербург, ул. Политехническая, д. 29, n.mostovsky@mail.ru;

Дауров Заур Сосланович - студент, кафедра строительства уникальных зданий и сооружений, СанктПетербургский политехнический университет Петра Великого (СПбПУ), 195251, г. Санкт-Петербург, ул. Политехническая, д. 29, zaur25k@gmail.com. 